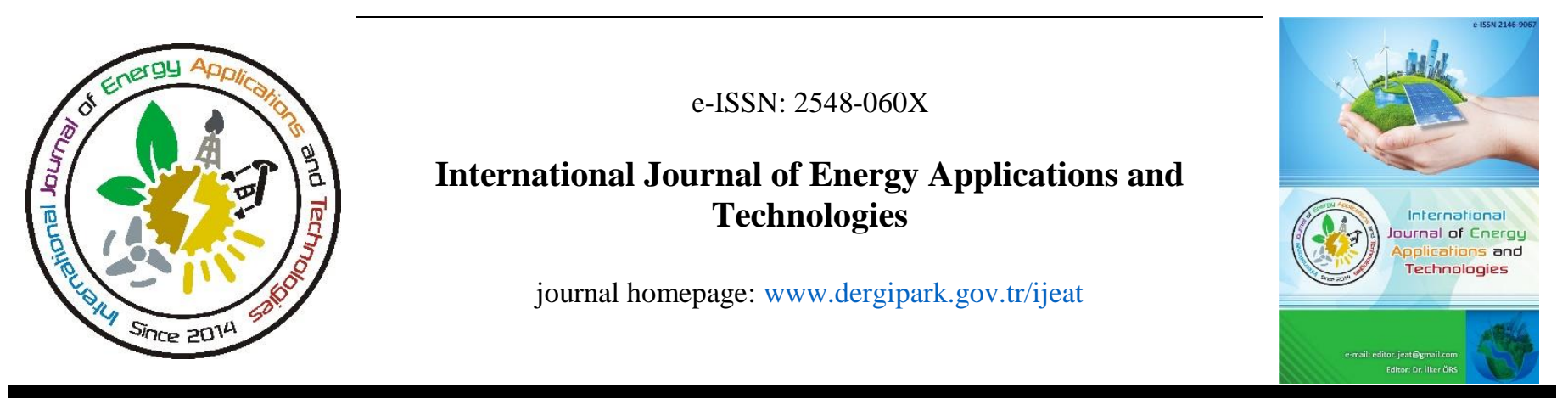

Original Research Article

\title{
Analysis of pollution load originating from cattle, small ruminant and poultry: A comparative case study for Isparta, Turkey
}

hosted by Turkish JournalPark

\author{
Kazım Kumaş ${ }^{1}$, Ali Akyüz ${ }^{2 *}$ \\ ${ }^{1}$ Department of Electricity and Energy, Bucak Emin Gülmez Technical Sciences Vocational School, Burdur Mehmet Akif Ersoy University, Burdur, Turkey \\ ${ }^{2}$ Department of Electronics and Automation, Bucak Emin Gülmez Technical Sciences Vocational School, Burdur Mehmet Akif Ersoy Uni., Burdur, Turkey
}

\author{
ARTICLE INFO \\ * Corresponding author \\ aakyuz@mehmetakif.edu.tr \\ Received July 4, 2020 \\ Accepted August 31, 2020 \\ Published by Editorial Board \\ Members of IJEAT \\ (C) This article is distributed by \\ Turk Journal Park System under \\ the CC 4.0 terms and conditions.
}

doi: 10.31593/ijeat.764217

\begin{abstract}
The animal wastes and bacteria in the fertilizer reach the water sources as a result of washing with precipitation and floods and cause deterioration of microbial quality. If the necessary precautions are not taken, it will be inevitable for wastes in livestock enterprises to pollute groundwater and resources as a potential pollutant. In this study, animal pollution load caused by spreading pollutant sources of Isparta center and its districts in Burdur basin was determined. In the pollution load calculation, 2019 animal numbers data were used according to three different animal species and the annual total nitrogen (TN) and total phosphorus (TP) loads were calculated. As a result of the calculation, the total TN load is 272.22 tons / year, total TP load was calculated as 8.45 tons / year. In addition, the district with the most widespread pollution load was determined and comparisons were made among the districts.
\end{abstract}

Keywords: Animal pollution load; Diffuse pollutants; Total nitrogen; Total phosphorus

\section{Introduction}

Despite the increasing need for water due to the rapid population growth, the scarcity of suitable resources is depressing. Problems experienced due to excessive water use and pollution that emerged in parallel with the developing industry and agricultural activities have increased the importance of water resources management, especially on basin basis. Despite the increasing need for water due to the rapid population growth, the scarcity of suitable resources is quite remarkable. The problems experienced due to excessive water use and pollution emerging in parallel with the developing industry and agricultural activities day by day have increased the importance of water resources management, especially on basin basis. One of the most important parameters of sustainable watershed management is to identify pollutant sources and to determine the appropriate strategy for the control of existing pollution. In order to determine a strategy for the protection of water resources, it is first necessary to identify the pollutant sources causing pollution in the receiving water environments [1]. Animal husbandry activities may cause contamination of surface and groundwater resources if controlled waste management is not applied. Depending on factors such as climate conditions, waste characteristics, feeding technique and techniques used in waste management, the negative effects of wastes on the environment may change. [2].

The direct access of cattle and small ruminant to the water source, surface runoff water from manure piles, shelters and open feeding areas, leaks from manure storage structures, flooding of storage areas, surface runoff water from fertilizer areas and pastures threaten drinking water sources [3,4]. More than $70 \%$ of surface and groundwater are used in agricultural irrigation in Turkey. Therefore, ensuring the protection and sustainability of Turkey's water resources is extremely important [5]. Turkey still has livestock in the 
event of a widespread agricultural sector. Some of the wastes from livestock activities are used as natural fertilizers in agriculture; the remaining part is collected in open warehouses under unsanitary conditions or poured into the nearest land. The spread N (nitrogen) and P (phosphorus) loads from animal wastes are also important pollutant sources coming to the basin. When animal wastes are used as natural fertilizers, the nitrogen and phosphorus unit loads spreading to the environment are highly variable depending on the animal category, type, feeding habits, weights and fertilization characteristics. Therefore, it is difficult to determine the unit loads [6].

Considering TN load distribution in Turkey, agricultural fertilizer use has the highest share with $35 \%$. Then, land use has a share of $33 \%$. Other parts are livestock (21\%), atmospheric transport (7\%), septic tank $(3 \%)$ and leachate (1\%). When the distribution of TP loads has been analyzed, it is seen that most of the loads have been caused by fertilizer use (54\%), animal husbandry following agricultural activities (23\%) and land use (14\%). Septic tank and leachate TP load distribution have $8 \%$ and $1 \%$, respectively [7].

In this study, TN (Total Nitrogen) and TP (Total Phosphorus) loads from agriculture and animal husbandry were calculated for Isparta, which has rich groundwater and groundwater potential.

\section{Materials and Method}

Isparta has 893.307 hectares (353.959 forests, 251.282 agriculture, 81.719 pastures) and is the center of the Göller region. While $77 \%$ are used agriculturally, 70.156 hectares are used as water surfaces and 136.191 hectares are used as other non-agricultural areas. Although the land structure of Isparta is mountainous and rugged, it also has important fresh water resources and fertile plains. Isparta is one of the important centers where cattle, sheep and poultry and freshwater fishing are carried out.

Livestock is one of the most important livelihoods of the people. Yalvaç, Şarkikaraağaç, Senirkent, Merkez and Sütçüler districts where the livestock activities are most intense. Wastewater originating from other settlements in the provincial boundaries is given directly to the land or streams in the vicinity, and activities such as animal husbandry and agriculture in the surrounding settlements pose a risk to human and environmental health. The use of unconscious drugs and fertilizers significantly affects soil and water pollution across the province where agriculture and animal husbandry are developed [8].

Isparta (Turkey Statistical Institute (TSI) -2019) number of animals are listed in Table 1 . When the total number of animals in the districts has been analyzed, the highest number of animals is in the central district, while the district with the least number of animals is Yenişarbademli [9].

Pollution load coefficients resulting from livestock activities are given in Table 2 [10]. In the load estimation calculation, the number of animals in Table 1 and the unit animal loads in Table 2 were used. As a result of multiplying the number of animals and load coefficients, the spread pollution load has been determined. $15 \%$ for nitrogen and 5\% for phosphorus were used to reach pollution caused by animal activities to the receiving environment.

Table 1. Animal Numbers [9]

\begin{tabular}{lccc}
\hline \multicolumn{1}{c}{ Districts } & Cattle & Small Ruminant & Poultry \\
\hline Aksu & 8377 & 9696 & 2174 \\
Atabey & 6266 & 20511 & 4555 \\
Ĕ̈irdir & 15059 & 70313 & 5151 \\
Gelendost & 6643 & 27796 & 16164 \\
Gönen & 5013 & 25129 & 7590 \\
Keçiborlu & 9636 & 20669 & 8588 \\
Merkez & 19626 & 83215 & 197042 \\
Senirkent & 4066 & 32691 & 893 \\
Sütçüler & 10749 & 39401 & 10605 \\
Uluborlu & 1694 & 15751 & 1099 \\
Yalvaç & 34722 & 122548 & 43690 \\
Yenişarbademli & 1550 & 3109 & 1959 \\
Şarkikaraağaç & 30089 & 66664 & 12374 \\
\hline
\end{tabular}

In the calculation of anthropocenic spread loads arising from animal husbandry activities, animal weights were accepted as $500 \mathrm{~kg}$ for cattle, $45 \mathrm{~kg}$ for small ruminant and $2 \mathrm{~kg}$ for poultry and the number of animals was distributed equally to the districts remaining in the basin [11].

Table 2. Load Coefficients Resulting from Livestock Activities [10]

\begin{tabular}{cccc}
\hline Animal Type & Cattle & Small Ruminant & Poultry \\
\hline $\begin{array}{c}\text { TN } \\
\text { (kg/animal/year) }\end{array}$ & 8.2 & 1 & 0.06 \\
TN & 0.30 & 0.42 & 0.52 \\
$\begin{array}{c}\text { (kg/ton animal mass/day) } \\
\text { TN to environment }\end{array}$ & 0.15 & 0.15 & 0.15 \\
$\begin{array}{c}\text { TP } \\
\text { (kg/animal /year) }\end{array}$ & 0.91 & 0.05 & 0.008 \\
TP (kg/ton animal mass/day) & 0.10 & 0.06 & 0.22 \\
TP to environment & 0.05 & 0.05 & 0.05 \\
\hline
\end{tabular}

\section{Results and Discussion}

TN and TP loads caused by animal wastes vary depending on the animal category, type, feeding habits, weight and fertilization feature. The nutrients that limit primary production in surface waters are nitrogen and phosphorus. These nutrients cause primary production to increase and eutrophication if they are found in large amounts in wastewater. TN and TP loads created by livestock activities reach surface and groundwater through infiltration. Therefore, TN and TP loads are important pollutant sources for water bodies. Concentrations of these pollutants should be taken into consideration in regions where livestock is concentrated $[12,13]$. 
Atabey and Gönen districts of Isparta (100\%), a large part of Keçiborlu district (87\%), a small part of the central district $(2.34 \%)$ and Sevinçbey and Bademli Villages (1.40\%) of the Eğirdir district are located in the Burdur basin. In the pressure impact analysis of the basin, nitrogen, phosphorus, etc. are among the pollutant sources from livestock activities. Such elements reach the water resources with superficial and artificial flows [14].

TN load distribution resulting from livestock activities of Isparta center and its districts can be seen in Table 3 . According to the animal species, the total TN load is mostly caused by cattle, while the least TN load is from poultry. TN load from cattles and small ruminants is mostly in Yalvaç district and the least is in Yenişarbademli district. The top three districts that have the highest proportion of TN load from cattles are Yalvaç, Şarkikaraağaç and Merkez districts, respectively. The three districts with the lowest TN rate are Yenişarbademli, Uluborlu and Senirkent districts, respectively. In poultry, the district that affects the TN load the most is the central district, while the least is Senirkent and Uluborlu districts. The total TN load of the districts in the basin is 35.21 tons / year.

Table 3. TN load from livestock activities (tons / year)

\begin{tabular}{lccc}
\hline \multicolumn{1}{c}{ Districts } & Cattle & Small Ruminant & Poultry \\
\hline Aksu & 10.30 & 1.45 & 0.02 \\
Atabey & 7.70 & 3.07 & 0.04 \\
Eğirdir & 18.52 & 10.54 & 0.05 \\
Gelendost & 8.17 & 4.16 & 0.14 \\
Gönen & 6.16 & 3.76 & 0.06 \\
Keçiborlu & 11.85 & 3.10 & 0.07 \\
Merkez & 24.13 & 12.48 & 1.77 \\
Senirkent & 5.00 & 4.90 & 0.01 \\
Sütçüler & 13.22 & 5.91 & 0.09 \\
Uluborlu & 2.08 & 2.36 & 0.01 \\
Yalvaç & 42.70 & 1.38 & 0.39 \\
Yenişarbademli & 1.90 & 0.46 & 0.02 \\
Şarkikaraağaç & 37.00 & 9.99 & 0.11 \\
\hline \multicolumn{1}{c}{ Total } & $\mathbf{1 8 8 . 8 0}$ & $\mathbf{8 0 . 6 2}$ & $\mathbf{2 . 8 0}$ \\
\hline
\end{tabular}

TP loads due to animal husbandry activities are given in Table 4. When the effects of animal species on total TP load are compared, cattles are in the first place, followed by small ruminants and poultry, respectively. Yalvaç district has the most impact on the TP load of cattles on a district basis with $22.62 \%$. The district that has the least impact on TP load is Yenişarbademli district with $0.01 \%$. When TP load is analyzed on the basis of small ruminants by districts, the highest effect is Merkez district with $15.48 \%$, while the least effect is the district of Yenişarbademli with $0.005 \%$. When the TP loads of poultry are examined, the district with the highest TP load was Merkez district, while the district with the lowest TP load was Senirkent.
Table 4. TP load due to livestock activities (tons / year)

\begin{tabular}{lccc}
\hline \multicolumn{1}{c}{ Districts } & Cattle & Small Ruminant & Poultry \\
\hline Aksu & 0.3811 & 0.0242 & 0.0008 \\
Atabey & 0.2851 & 0.0512 & 0.0018 \\
Eğirdir & 0.6851 & 0.1757 & 0.0020 \\
Gelendost & 0.3022 & 0.0694 & 0.0064 \\
Gönen & 0.2280 & 0.0628 & 0.0030 \\
Keçiborlu & 0.4384 & 0.0516 & 0.0034 \\
Merkez & 0.8929 & 0.2080 & 0.0788 \\
Senirkent & 0.1850 & 0.0817 & 0.0003 \\
Sütçüler & 0.4890 & 0.0985 & 0.0042 \\
Uluborlu & 0.0770 & 0.0393 & 0.0004 \\
Yalvaç & 1.5798 & 0.3063 & 0.0174 \\
Yenişarbademli & 0.0705 & 0.0077 & 0.0007 \\
Şarkikaraağaç & 1.3690 & 0.1666 & 0.0049 \\
\hline \multicolumn{1}{c}{ Total } & $\mathbf{6 . 9 8 3 7}$ & $\mathbf{1 . 3 4 3 7}$ & $\mathbf{0 . 1 2 4 7}$ \\
\hline
\end{tabular}

\section{Conclusions}

Isparta is one of the important centers where cattle, small ruminant and poultry and freshwater fishing are carried out. Domestic sheep species and hair goats are widely cultivated in the city and animal husbandry is among the important livelihoods of the people. While some of the animal wastes are used as natural fertilizers in agriculture; the rest of it is stored in an uncontrolled way or it is thrown in empty lands. TN and TP loads from animal wastes in Burdur Basin are among the important pollutant sources coming to the basin. For this reason, pollution load due to livestock activities of Isparta provinces and districts in Burdur basin, which has protected and important surface water resources and rich groundwater potential, has been calculated. Cattle, small ruminant and poultry numbers from the data of the 2019 Turkey Statistical Institute (TUIK) were obtained.

TN and TP loads were calculated using load coefficients resulting from livestock activities. As a result of the calculation, while the total TN load is 272.22 tons / year, the TP load is 8.45 tons / year. Yalvaç is with the highest TN and TP loads on a district basis, with 61.48 tons / year and 1.90 tons / year, respectively.

The district with the lowest TN and TP loads is Yenişarbademli with 2.39 tons / year and 0.07 tons/ year. These calculated data are very important in terms of giving an idea to the future Burdur basin projects. This type of analysis is very important in the development of management and planning strategies for the reduction of pollution sources and pollution loads, especially livestock activities, to be carried out in Isparta city center and its districts in the coming years. The effects of diffuse and spot pollutant sources other than animal husbandry activities should be investigated and detailed monitoring studies should be conducted. 


\section{$\underline{\text { ORCID }}$}

Kazım Kumaş

$0000-0002-2348-4664$

Ali Akyüz

0000-0001-9265-7293

\section{References}

[1] Sahaym, U. and Norton, M. G. 2008. Advances In The Application of Nanotechnology in Enabling a Hydrogen Economy. Journal of Materials Science, 43, 5395-5429.

[2] Teira-esmatges, M.R. and Flotats, X. 2003. A Method for Livestock Waste Management Planning in NE Spain, Waste Management, 23 (10), 917-932.

[3] Salihoğlu, N. K. Teksoy, A. and Altanöhü K. 2019. Determination of Biogas Production Potential From Cattle and Sheep Wastes: Balıkesir Case Study, Omer Halisdemir University Journal of Engineering Sciences, 8(1), 31-47.

[4] Oun, A., Kumar, A., Harrigan, T., Angelakis, A. and Xagoraraki, I. 2014. Effects of Biosolids and Manure Application on Microbial Water Quality in Rural Areas in the US", Water, doi:10.3390/w6123701, 6, 37013723.

[5] Boyac1, S., Akyüz, A. andKükürtcü, M. 2011. Büyükbaş Hayvan Barınaklarında Gübrenin Yarattığı Çevre Kirliliği ve Çözüm Olanakları. Tarım Bilimleri Araştırma Dergisi, 4 (1), 49-55.

[6] Ceyhan HKEP, 2016.Çevre ve Şehircilik Bakanliği Ceyhan Havzasi Kirlilik Önleme Eylem Planı, 113s.

[7] (BHKP,2016).Orman ve Su İşleri Bakanliği Burdur Havzas1 Koruma Plan1,36s.

[8] (https://www.bagev.org.tr/bati-akdeniz-bolgesidetay_isparta-2083566156.html).

[9] TUIK istatistik verileri, 2019. https://biruni.tuik.gov.tr/medas/?locale $=$ tr

[10] Demir Yetiş, A., Teke, R. B. and Yetiş, R. 2018. Calculation of Pollution Load Originating from Animals of Muş Center and Districts, 6th International GAP Engineering Conference - GAP2018, 527-532.

[11] Derin, P., Demir Yetiş, A., Yeşilnacar, M. İ. and Yetiş, R. 2019. Determination of Animal Pollution Load from Anropogenic Diffuse Pollutant Sources for Mardin Central and Districts, 72nd Geological Congress of Turkey with international participation, 28 January-01 February, 694-698, Ankara, Turkey.

[12] Akdoğan, Z., Küçükdoğan, A. and Güven, B. 2015. Nonpoint Source Pollutant Transport in Watersheds: Modelling Approaches for Antibiotics, Heavy Metals and Nutrients, Marmara Fen Bilimleri Dergisi, 1, 2131.

[13] Anonymous, 2005a. Code of Good Agricultural Practice for the Prevention of Pollution of Water Department of Agriculture and Rural Development. $164 p$, UK.

[14] Tarım ve Orman Bakanlığı, Burdur Havzası Taşkın Yönetim Planı, 2019, 233s. 